\title{
Mistyczne znaczenie pokarmu
}

\author{
Mariusz Kiślak \\ Chrześcijańska Akademia Teologiczna, Wydział Teologiczny Polska \\ ORCID: 0000-0003-0802-8705 \\ mkislak@student.chat.edu.pl
}

rev. M. Kiślak, The mystical meaning of food, Elpis, 23 2021: 155-159.

\begin{abstract}
The article attempts to present the mystical meaning of food. Through food, the bond between God and man is broken, through food, which is the Eucharist, this bond is restored. Moreover, during the liturgical year, the Church sanctifies the matter and the whole world in the rites of blessing the food and produce of the earth.

Streszczenie: W artykule podjęta jest próba przedstawienia mistycznego znaczenia pokarmu. Przez pokarm zostaje rozerwana wieź między Bogiem a człowiekiem, poprzez pokarm, którym jest Eucharystia więź ta zostaje przywrócona. Ponadto Cerkiew w obrzędach poświęcenia pokarmów i płodów ziemi w przeciągu roku liturgicznego uświęca materię i cały świat.
\end{abstract}

Keywords: food, bread, creation, life, the Eucharist

Slowa kluczowe: pokarm, chleb, stworzenie, życie, Eucharystia

Trudno nie zauważyć, iż ostatnimi czasy kultura masowa dużo uwagi poświęca kwestiom żywienia. Popularne są programy i teleturnieje kulinarne. Dużo się mówi o zdrowym lub niezdrowym żywieniu. Wszędzie można napotkać porady dotyczące zrzucenia zbędnych kilogramów i informacje poświęcone właściwościom poszczególnych produktów. Z punktu widzenia dietetyki i fizjologii spożywany pokarm jest rozkładany na czynniki pierwsze jako czysto materialna funkcja człowieka. Refleksja nad pożywieniem sprowadza się do konkluzji Feuerbacha: „Człowiek jest tym co je" (Schmemann, 1988, s. 7). Mogło by się wydawać, że myśl chrześcijańska, stoi w opozycji do egzystencjonalnej. W istocie rzeczy tak nie jest. Chrześcijaństwo potwierdza myśl materialnego egzystencjonalizmu, jednakże uzupełnia ją i nadaję metafizyczną głębię (Schmemann, 1988, s. 7). Twierdzi, że otaczający człowieka świat materialny nie stoi w opozycji do potrzeb duchowych człowieka i ukazuje duchową stronę świata stworzonego (Schmemann, 1988, s. 10). Jak mówi św. Jan Damasceński: „Nie ma bowiem ani jednego żywego stworzenia, ani jednej rośliny, w której by nie założył Stwórca jakiejś wartości mogącej służyć ku pożytkowi ludzi. Zanim człowiek popełnił wykrocznie były mu uległe wszystkie stworzenia, ponieważ miał panowanie od Boga nad wszystkim, co znajdowało się na ziemi i w wodach" (Jan Damasceński, 1969, s. 93).

Wszystko co stworzył Bóg jest darem dla człowieka, aby ten w stworzonym życiu mógł poznawać swojego Stwórcę (Schmemann, 1988, s. 7). Świat jest miłością Bożą, ze względu na człowieka uczyniony jego pokarmem, jego życiem. Bóg błogosławi wszystko co stworzył i w języku Biblii oznacza to, że całość stworzenia uczynił On znakiem i środkiem swej obecności, swej mądrości, miłości i swego objawienia: Skosztujcie i zobaczcie, jak dobry jest Pan (Ps 33,9) (Schmemann, 1988, s. 10).
W biblijnej opowieści o stworzeniu świata człowiek przedstawiony został przede wszystkim jako istota odczuwająca głód, a wszystek świat - jako jego pożywienie (Schmemann, 1988, s. 10). Bóg sam sobie stawia za zadanie zaspokoić głód swojego stworzenia: Oto daje wam wszelka rośline wydajaca nasienie na całej ziemi i wszelkie drzewa, których owoc ma w sobie nasienie: niech będzie dla was pokarmem $(\mathrm{Rdz} 1,29)^{1}$.

Z pokarmem także jest związany pierwszy zakaz dany człowiekowi przez Boga. I dał Pan Bóg człowiekowi taki rozkaz: Z każdego drzewa tego ogrodu możesz jeść, ale z drzewa poznania dobra i zła nie wolno ci jeść, bo gdy tylko zjesz z niego, na pewno umrzesz ( $R d z ~ 2,16-17)$. To właśnie przez pokarm dochodzi do upadku człowieka. Zjedzenie zakazanego owocu powoduje metahistoryczną katastrofę. Ziemia zaczyna rodzić ciernie, a chleb zdobywany jest w pocie czoła. Ponieważ ustuchałeś głosu żony swojej i jadłeś z drzewa, z którego ci zabroniłem, mówiąc: Nie wolno ci jeść z niego, przeklęta niech będzie ziemia powodu ciebie! W mozole żywić się będziesz z niej po wszystkie dni życia swego! Ciernie i osty rodzić ci będzie i żywić się będziesz zielem polnym. W pocie oblicza twego będziesz jadt chleb, aż wrócisz do ziemi, z której zostateś wzięty; bo prochem jesteś $i$ w proch się obrócisz ( $\mathrm{Rdz} 3,17-19)$.

„Owoc ten różnił się on od pozostałych owoców: nie był darem zaoferowanym, człowiekowi. Nie podarowany i nie pobłogosławiony przez Boga był pokarmem samym w sobie, a nie w Bogu. Był obrazem świata kochanego w oderwaniu od Boga, dla niego samego (Schmemann, 1988 , s. 12). Biblijny opis przedstawia to w sposób następujący: A gdy kobieta zobaczyła, że drzewo to ma owoce

1 Cytaty z Pisma Świętego Starego i Nowego Testamentu za Biblia, Brytyjskie i Zagraniczne Towarzystwo Biblijne, Warszawa 1975. 
dobre do jedzenia i że byty mite dla oczu, i godne pożądania dla zdobycia madrości, zerwała z niego owoc i jadła. Dała też mężowi swemu, który byt z nia, i on też jadt (Rdz $3,6)$. Człowiek przywykł żyć nie zanosząc dziękczynienia za świat darowany mu przez Boga, po prostu tak zwyczajnie utracił eucharystyczny stosunek do Boga (Schmemann, 1988, s. 12). A przecież jest nie tylko królem stworzenia lecz uczyniony został przez Boga jego kapłanem. Tylko człowiekowi zostało dane składać dziękczynienie i błogosławić Boga za darowane mu przezeń pożywienie i życie (Schmemann, 1988, s. 12).

Aby żyć, człowiek musi jeść. Pokarm jest naturalną komunią - więź z ciałem świata. Kiedy przyjmuję pokarm, spożywam materię jako taką, i tym samym realnie odnajduję ten świat w sobie, a siebie w świecie, staje się jego częścią. Pod postacią chleba spożywam ciało całego świata. Gdyż w historii tego chleba, tak samo jak w każdym okruszku, zamknięta jest historia całego wszechświata (Schmemann, 1988, s. 12).

Prawosławny Euchologion (Euchologion. Tom 1, 2016; Euchologion. Tom 2, 2016) zawiera szereg modlitw na błogosławieństwo pokarmów: ziarna siewnego, winogron, wina, miodu, oleju, soli. We wszystkich modlitwach i obrzędach dotyczących poświęcenia pokarmów można dostrzec prawidłowość prośby o błogosławieństwo, uświęcenie darów, zesłanie łaski na dary by właściwości w nich założone mogły pomagać, leczyć a człowiek przez sam akt spożycia i korzystania z owoców pracy wysławiał Trójcę Przenajświętszą. Aby ziemia i wszystko co ją wypełnia była błogosławiona.

Za przykład niech posłuży modlitwa pobłogosławienia nowego miodu:

„Nieogarniony w miłosierdziu i niewypowiedziany w litości Panie Jezu Chryste, przedziwny jesteś w chwale i czynisz cuda. Ty działaniem Świętego Ducha niegdyś pobłogosławiłeś Izraela i nasyciłeś go miodem z kamienia, sam i teraz wejrzyj z wysoka na Twoje stworzenia i błogosławieństwem Twoim niebieskim pobłogosław plastry i z nich miód, i daj mu doskonałą łaskę, aby każdy spożywający go, przyjmujący i jedzący otrzymał potrzebne zdrowie i nasycił się tym pokarmem, i napełnił wszelkim dobrem. Albowiem Ty jesteś dawcą wszystkich dóbr i Tobie chwałę oddajemy z Ojcem Twoim nie mającym początku i z najświętszym, i Dobrym, i Życiodajnym Twoim Duchem, teraz i zawsze, i an wieki wieków. Amen" (Modlitwa na zrywanie winogron, w: Euchologion. Tom 2, 2016, s. 88).

Taką samą wymowę uzyskuje modlitwa poświęcenia pokarmów podczas wieczerni:

„Panie Jezu Chryste, Boże nasz, który pobłogosławiłeś pięć chlebów i pięć tysięcy nakarmiłeś, sam pobłogosław te chleby, pszenicę, wino i olej, i pomnóż je w tym mieście, i w całym Twoim świecie, i uświęć tych, którzy będą je spożywali. Albowiem ty błogosławisz i uświęcasz wszystko, Chryste Boże nasz, i Tobie Chwałę oddajemy z Przedwiecznym Twoim Ojcem, i z Najświętszym, i Dobrym, i Życiodajnym Twoim Duchem, teraz i zawsze, i na wieki wieków" (Wieczernia, jutrznia, prokimenony, alleluja, rozestania, kalendarz liturgiczny, 2006, s. 39-40).
Jak również pokarmów w dzień Zmartwychwstania:

„Wejrzyj, Panie Jezu Chryste, Boże nasz, na pokarmy mięsne i poświęć je, jak poświęciłeś baranka, którego złożył Tobie wierny Abraham, i baranka, którego ofiarował Tobie Abel w ofierze całopalnej. Podobnie i cielca utoczonego, którego nakazałeś zabić dla syna Twego marnotrawnego, który powrócił do Ciebie, i jak on stał się godnym słodyczy Twojej łaski, tak i niech będą poświęcone przez Ciebie i pobłogosławione te mięsa na pokarm dla nas wszystkich. Ty bowiem jesteś prawdziwym pokarmem i dawcą dóbr, i Tobie chwałę oddajemy z Ojcem Twoim niemającym początku, i z Najświętszym, i Dobrym, i życiodajnym Twoim Duchem, teraz i zawsze, i na wieki wieków. Amen" (Modlitwa pobłogosławienia mięs w Niedzielę Paschy, w: Pentekostarion, 2021, s. 14).

„Władco, Panie Boże nasz, Stwórco i Twórco wszystkiego, pobłogosław ser, a wraz z nim i jajka, i nas zachowaj w Twojej łasce, abyśmy je spożywając napełnieni zostali Twoimi darmo dawanymi darami i niewypowiedzianą Twoją łaską. Albowiem Twoje jest panowanie i Twoje jest królestwo, i moc, i chwała, Ojca i Syna, i Świętego Ducha, teraz i zawsze, i na wieki wieków. Amen" (Modlitwa pobłogosławienia sera i jaj, w: Pentekostarion, 2021, s. 14).

Chrześcijanin pragnie aby poprzez spożywanie błogosławionych i uświęconych pokarmów uświęcało się również jego ciało i dusza. Obecność modlitw w prawosławnym Euchologionie i praktyce liturgicznej ukazuje tęsknotę człowieka za stanem z przed upadku. Człowiek dziękuję Bogu i dokłada starań aby ukazać swoją świadomość, że płody jakie rodzi ziemia są darami od Boga. Teksty modlitw wyrażają tęsknotę za rajem i są wyrazem posłuszeństwa. Wskazują chęć korzystania z darów Bożych zgodnie z pierwotną wolą Boga, inaczej niż to było w przypadku Adam i Ewy.

Powyższe rozważania znajdują potwierdzenie w autorytecie liturgicznym św. Bazylego Wielkiego, który w anaforze eucharystycznej umieszcza takie oto słowa w odniesieniu do pokarmu:

„Rozraduj także i odnów oblicze ziemi, bruzdy jej napój, pomnóż jej plony. Daj nam wszystko, co jest potrzebne do zasiewów i do żniwa oraz już teraz pobłogosław. Życiem naszym kieruj. Pobłogosław krąg roku dobrodziejstwami Twymi ze względu na biedny Twój lud, ze względu na wdowy i sieroty, ze względu na pielgrzymów i przybyszów, i ze względu na nas wszystkich, pokładających w Tobie nadzieję przyzywających święte Twoje imię. Oczy bowiem wszystkich w Tobie pokładają nadzieję i Ty dajesz pokarm wszystkim we właściwym czasie. Uczyń z nami według Twojej łaskawości, Ty który dajesz pokarm każdemu ciału. Napełnij radością i szczęściem nasze serca, byśmy wszystko mieli w obfitości w każdym dobrym dziele, aby czynić Twoją świętą wolę" (Paprocki, 1988, s. 241).

Kościół dostrzega w człowieku kosmiczną moc i Pan, który uświęcił ziemię i wody Jordanu, również teraz uświęca je przez Ducha Świętego, posyłanego kościołowi przez Ojca. Uświęcenie natury związane jest $\mathrm{z}$ uświęce- 
niem duchowym, a my sami uświęcamy się przez spożywanie poświeconej materii, np. chleba, wody, na wzór tego wielkiego poświecenia które zostało nam dane przez Chrystusa w chlebie żywota, w Boskiej Liturgii. W niej uświęca się materia świata, przemieniana w ciało i krew Chrystusa i nam dająca wspólnotę z Nim (Bułgakow, 1992, s. 154).

Bez błogosławieństwa bożego wszelkie działanie człowieka jest daremne, dlatego Chrystus uczy nas modlitwy: „Chleba naszego powszedniego daj nam dzisiaj” (Mt 6,11). Jednakże nie samym chlebem żyje człowiek, ale każdym stowem pochodzacym z ust Bożych (Mt 4,4). Są to słowa, którymi Chrystus odpędza pokusę szatana, kiedy ten podejmuje próbę kuszenia (Mt 4, 1-4). Chrystus przytaczając słowa z Księgi Powtórzonego Prawa $(8,3)$ wskazuje, że istnieje również pokarm duchowy - słowo Boże, wola Boża.

Kolejnym bardzo istotnym momentem ukazującym duchowe znaczenie pokarmu jest cudowne rozmnożenie chleba i nakarmieniu pięciu tysięcy ludzi. Sekwencja następujących wydarzeń pozwala postawić tezę, że rozmnożenie chlebów jako zaspokojenie fizycznego głodu było wstępem do ukazania pokarmu duchowego, chleba, który zaspakaja głód duchowy i daje życie wieczne. Chrystus neguje postawę ludzi, których motywacją do podążania za nim było zaspokojenie fizycznego głodu $(\mathrm{J}$ 6, 26) (Adamczyk, 2006). Nie chce żeby widzieli w nim kogoś kto rozwiązuje problemy gospodarcze. Pragnie, by inaczej rozłożyli akcenty w swoim życiu: Zabiegajcie nie o pokarm się, który ginie, ale o pokarm który trwa o pokarm żywota wiecznego, który wam da Syn Człowieczy (J 6, 27) (Forestner, 1990, s. 456). Mówiąc alegorycznie nazywa siebie chlebem, tym niezbędnym do życia produktem: Jam jest chleb żywota. Ojcowie wasi jedli mannę na pustyni i poumierali. Tu natomiast jest chleb, który zstepuje z nie$b a$, aby nie umart ten, kto go spożywa. Ja jestem chlebem żywym, który z nieba zstapil; jeśli kto spożywać będzie ten chleb, żyć będzie na wiek, a chleb który ja dam to ciato moje, która ja oddam za żywot świata. (J 6, 48-51) Nowy chleb jakim jest Chrystus daje gwarancję życia wiecznego i jedności z Synem Człowieczym: Zaprawdę, zaprawdę powiadam wam, jeśli nie będziecie jedli ciała Syna Człowieczego i pili krwi jego, nie będziecie mieli żywota w sobie. Kto spożywa ciato moje i pije krew moja, ten ma żywot wieczny, a Ja go wskrzesze w dniu ostatecznym. Albowiem ciało moje jest prawdziwym pokarmem, a krew moja jest prawdziwym napojem. Kto spożywa ciato moje i pije krew moja, we mnie mieszka a ja w nim (J 53, 56).

Chrześcijaństwo poprzez modlitwę św. Ambrożego Mediolańskiego odpowiada Chrystusowi w sposób następujący:

„Proszę cie Panie, ze względu na sakrament świętego Twojego ciała i krwi twojej, którym zawsze w świątyni twojej karmieni i napojeni, oczyszczani, uświęcani i zjednoczeni jesteśmy, abyśmy siłą twoją wzmocnieni, z czystym sumieniem przystąili do twego ołtarza, niebiańskie tajemnice mając w sobie dla życia i zbawienia, wg słów twoich: chleb, który wam daję, ciałem moim jest, które wam daję za życie świata: spożywający mnie będzie żywy ze względu na mnie. Chlebie najsłodszy, ulecz usta serca mego, abym poczuł w sobie słodycz Twojej miłości: ulecz wszelką niemoc, abym poza Toba nie pożądał żadnego piękna! Chlebie najczystszy, wszelkiej słodyczy i przepięknej woni wypełnienie, wejdź do mojego serca i słodyczą twojego zapachu wypełnij wnętrze mojej duszy. Tobą karmią się obficie aniołowie w niebie: niech wg swoich sił nasyci się Tobą i przybysz człowiek na ziemi. Chlebie święty, chlebie żywy, chlebie upragniony, schodzący z niebios i dający życie światu, przeniknij do mojego serca i oczyść mnie od wszelkiej nieczystości ciała i ducha. Przeniknij do mojej duszy, uświęć ją z zewnątrz i wewnątrz, uświęcając i oświecając. Bądź zawsze ochroną mojej duszy i zdrowiem ciała. Odpędź ode mnie napadających na mnie, niech uciekną wszyscy sprzed Twojego oblicza, którzy mnie nienawidzą: abym Tobą chroniony, z Tobą przeszedł do wiecznego Twojego królestwa gdzie twarzą w twarz ciebie ujrzymy, kiedy przekażesz królestwo Bogu i Ojcu, aby Bóg był wszystkim we wszystkich. Do tej pory pragnę i łaknę, ale gdy to nastąpi będę nasycony, kiedy ujrzę Twoją chwałę, w której królujesz wraz z Ojcem i Świętym Duchem na wieki wieków. Amen" (Molitva svâtogo Amvrosiâ episkopa mediolânskagopresviterov gotovâsimsâ k služeniû svâtyâ liturgii, w: Kanonnik, 1986, s. 522).

Rozważania o mistycznym znaczeniu pokarmu doprowadziły nas do Eucharystii. Uwieńczeniem mistycznego znaczenia pokarmów jest chleb i wino w akcie ofiarowania i przemiany w Ciało i Krew Chrystusa (Forestner, 1990 , s. 455). Pokarmy te są „realnym symbolem” naszego życia, gdyż od ich spożycia zależy nasze życie wieczne. W ich ofiarowaniu, przynosimy Bogu samych siebie, swoje życie i życie całego świata, który jest dla nas pożywieniem i życiem. W akcie przynoszenia składamy Bogu dzięki i w ten sposób człowiek spełnia się w roli „króla, kapłana i proroka", którego zadaniem jest przeobrażać swoje i świata oblicze w życie i obcowanie z Bogiem. Dary te są przynoszone w imieniu całego stworzenia" (Schmemann, 1988, s. 28). Znajduje to wyrażenie w słowach Liturgii: „To, co Twoje, od Twoich, Tobie przynosimy, za wszystkich i za wszystko" (Boska liturgia świętego ojca naszego Jana Chryzostoma, 2001, s. 81), które kapłan wypowiada podczas kanonu eucharystycznego. W Eucharystii chrześcijanie znajdują łączność z Bogiem przez Chrystusa, nowego Adama (Langkammer, 1985, s. 142).

Jeśli jedzenie jest spożyciem ciała ziemi, nie zależnie od swojej formy i ilości, to spożycie ciała i krwi Chrystusa pod postacią chleba i wina jest spożyciem Ciała Syna Bożego. Jeśli jedzenie podtrzymuje śmiertelne życie, to Eucharystyczna uczta jest spożyciem i udziałem w życiu nieśmiertelnym, w którym ostatecznie zwyciężona jest śmierć i przezwyciężona martwa nieprzeniknioność materii. Poprzez wcielenie Boga zostało stworzone nowe, duchowe ciało - ciało świata, które otrzymało potencję bycia nieśmiertelnym, i jej przyszłą realizację przeobrażenia w Sakramencie Eucharystii. W tym znaczeniu można powiedzieć, że święty pokarm Eucharystii jest „lekarstwem na nieśmiertelność.” Jest pokarmem, który prowadzi do życia nieśmiertelnego, oddzielonego od teraźniejszego progiem śmierci i zmartwychwstania. Podobnie jak 
w przypadku kiedy spożywamy ciało świata, przyjmujmy w siebie świat z jego śmiertelnym życiem, i spożywając ten pokarm umieramy, to spożywając chleb, który zszedl $z$ niebios przyjmujemy do swojego wnętrza jego życiodajną siłę (Bulgakov, 2008, s. 43).

Jeśli pokarm, wg Sergiusza Bułgakowa, jest komunią ze światem, to człowiek uświęcając pokarm w imię Trójcy Świętej, taką uświęconą materię przyjmuje w siebie (Bulgakov, 2008, s. 43). Materia jest przenikana przez Energię Świętego Ducha czyniąc ją „Bogonośną” (Hrycuniak, 1984, s. 90). Szczególne znaczenie ma poświęcenie wody w święto Chrztu Pańskiego. Praktyka Liturgiczna przewiduje dwa poświęcenia wody. Jedno w wigilię święta Epifanii na użytek domowników i drugie w dzień święta. Poświęcana jest woda w naturalnych zbiornikach, rzekach, morzach i oceanach. W ten sposób uświęconą materię spożywa wszystko co żyje. Rośliny, zwierzęta i wszystkie stworzenia (Kiślak, 2003, s. 24). Analogiczną praktykę widzimy w rytach poświęcenia pokarmów w przeciągu roku liturgicznego. W ten sposób człowiek spełnia swoją rolę kapłańską. Poprzez swoją kapłańską działalność uświęca otaczający świat. W Eucharystii swoje apogeum znajduje mistyczne znaczenie pokarmów. Poprzez pokarm została rozerwana wieź człowieka z Bogiem. Poprzez pokarm wieź człowieka ze Stwórcą zostaje przywrócona.

Bez spożywania pokarmów życie jest niemożliwe. Człowiek tak został stworzony, że aby żyć musi czerpać z zewnątrz. Życie zależy od pokarmu, który daje człowiekowi Bóg. Człowieka zależny jest od Boga (Bondaruk, 2019, s. 137-138).

Pokarm wskazuje również na panowanie człowieka w świecie. Otrzymał on świat we władanie i pokarm miał czerpać z pracy własnych rąk. Pokarm używany podczas Eucharystii, chleb i wino, są produktami przyrody, ale także owocami pracy rąk ludzkich. W Eucharystii Bóg utwierdza władzę człowieka nad przyrodą. W ten sposób godzi się na obecność owocu ludzkiej pracy w Jego kulcie. Przepracowane pożywienie symbolizuje naszą kreatywność, która jest istotą podobieństwa do Boga (Bondaruk, 2019, s. 137-138).

Wspólne spożycie pokarmu podkreśla wspólnotę człowieka. Założona w pokarmie mistyka, powoduje, że podczas spożywania posiłku, łamania chleba, niejako automatycznie stajemy się rodziną. Podobnie eucharystyczny chleb i wino czynią z nas wspólnotę wiernych, rodzinę chrześcijańską (Bondaruk, 2019, s. 137-138).

Pokarm od zarania dziejów stanowił także centrum kultu. Wspólnota narodu z Bogiem była podtrzymywana przez dzielenie się pożywieniem, ofiarami ze zwierząt lub płodów ziemi. Dlatego też w ewangelicznej historii o wskrzeszeniu córki Jaira (Łk 8, 49-56), Chrystus nakazuje podanie posiłku. Fakt ten wskazuje na pokój ustanowiony przez Chrystusa pomiędzy człowiekiem i jego bliźnim, między Bogiem i pozostałym stworzeniem. W życiu człowieka odnowione zostają normalne relacje z Bogiem, jak również ukazuje powrót śmierci na właściwe jej miejsce. Śmierć pozbawiona żądła grzechu. Już nie służy diabłu i nie czyni człowieka niewolnikiem szatana $\mathrm{z}$ powodu lęku przed nią, ale odtąd służy życiu stając się drzwiami, które prowadzą od chwały ku chwale (Bondaruk, 2019, s. 137-138).

Warto również zauważyć, iż pokarm posłużył Chrystusowi jako dowód na prawdziwość Jego zmartwychwstania. Lecz gdy oni z radości jeszcze nie wierzyli i petni byli zdumienia, rzekt do nich: „,Macie tu co do jedzenia?” Oni podali mu kawatek ryby i plaster miodu. A on wziat i jadt przy nich (Łk 24, 41-42).

Mistyczne znaczenie pokarmu w kontekście eschatologicznym odnajdujemy w przypowieści o Sądzie Ostatecznym (Mt 23,31-46). Według wymienionych kryteriów Chrystus będzie sądził każdego człowieka, kiedy przyjdzie po raz drugi. Dwa z sześciu dotyczą pokarmu: Albowiem taknątem, a daliście mi jeść, pragnąem a daliście mi pić (Mt 25, 35). Podzielenie się pokarmem z potrzebującym jest aktem miłosierdzia, który toruje drogę do Królestwa Bożego. Zlekceważenie znaczenia roli pokarmu może stać się poważną przeszkodą na drodze ku niemu.

Pokarm niejednokrotnie, w różnych kontekstach pojawia się na kartach Pisma Świętego. Już w Starym Testamencie spotykamy praobraz Eucharystii, o której mowa za pomocą chleba: chleb, który składa w ofierze Melchizedek (Rdz 14,18), manna na pustyni (Wj 16,4), podpłomyk przygotowany dla Eliasza (1Krl 17,13) i wiele innych. Pokarm a w szczególności chleb jest narzędziem, ukazującym mistyczne znaczenie pokarmu. Służy do zrozumienia świata, relacji człowieka z Bogiem i człowieka ze światem. Mistyczne znaczenie pokarmu cerkiew zrozumiała i przekazuje swoim wiernym w nauce o Eucharystii jak również w szeregu modlitw i obrzędów na poświęcenie pokarmów i płodów pracy człowieka.

Zagadnienie pokarmu może się wydawać oczywistym. Jest to jednak temat szeroki i wielowątkowy. Znacznie wybiegający poza ramy niniejszego artykułu. Spożywanie pokarmu jest $\mathrm{w}$ istocie rzeczy walką człowieka o życie. „Z natury bowiem pokarm zmysłowy tylko uzupełnia to, co w nas się zużywa, a potem ulega wydaleniu i ginie. Dlatego zniszczeje ten, kto na zmysłowym pokarmie tylko pozostaje" (Jan Damasceński, 1969, s. 93). Przestrzega św. Jan Damasceński. Pokarm może być nośnikiem łaski Bożej, ale źle wykorzystany może stanowić zagrożenie dla zdrowia fizycznego i duchowego (Leśniewski, 2006, s. 176). Ascetyka chrześcijańska pokarmom poświęca wiele miejsca. Cerkiew także poprzez zalecenia postu, czyli $\mathrm{m}$. in. czasowego powstrzymania spożycia określonych pokarmów. Troska cerkwi o wiernych stwarza rodzaj kalendarza kulinarnego na każdy dzień i odpowiednio do trwającego roku liturgicznego (Mineâ, dekabr', 1982, s. 357)². Powyższy artykuł podejmuje próbę zwrócenia uwagi, że wszelki pokarm jest darem od Boga i że cud rozmnożenia chleba trwa każdego dnia. W każdym spożywanym posiłku zachodzi cała gama mistycznych procesów, z których nie do końca zdajemy sobie sprawę w codziennym życiu.

2 Jeśli dla przykładu, święto Narodzenia Chrystusa przypadnie w środę albo w piątek, świeckim wiernym pozwala się spożywać mięso, mnichom zaś ser i jajka, i spożywamy tak od Narodzenia Chrystusa przez wszystkie dni do wigilii Świętej Epifanii. 


\section{Bibliografia}

Adamczyk, D. (2006). Chleb życia. Kieleckie Studia teologiczne, t. 5. s. 9-25.

Biblia. (1975). Warszawa: Brytyjskie i Zagraniczne Towarzystwo Biblijne.

Boska liturgia świętego ojca naszego Jana Chryzostoma. (2001). Warszawa.

Bondaruk, K. (2019). Homilie niedzielne. Białystok.

Bulgakov, C. (2008). Filosofiâ Hozâjstva. Moskva.

Bułgakow, S. (1992). Prawosławie. Białystok.

Euchologion. Tom 1. (2016). Warszawska Metropolia Prawosławna.

Euchologion. Tom 2. (2016). Warszawska Metropolia Prawosławna.

Forestner, D. (1990). Świat symboliki chrześcijańskiej. Warszawa.

Hrycuniak, S. (1984). Nauka Ojców Kościoła o świętych sakramentach. Rocznik Teologiczny XXVI. z. 2.
Jan Damasceński (św.) (1969). Wyktad wiary prawdziwej. Warszawa.

Kanonnik. (1986). Moskva.

Kiślak, M. (2003). Mistyczne znaczenie wody. Cerkiewny Wiestnik, $1 / 2003$.

Langkammer, H. (1985). Etyka Nowego Testamentu. Wrocław.

Leśniewski, K. (2006). Nie potrzebują lekarza zdrowi... Hezychastyczna metoda uzdrawiania człowieka. Lublin.

Mineâ, dekabr'. (1982). Moskva.

Paprocki, H. (1988). Wieczerza Mistyczna Anafory Eucharystyczne chrześcijańskiego Wschodu. Warszawa.

Paprocki, H. (red.). (2021). Pentekostarion. [online] http://www. liturgia.cerkiew.pl/pages/File/docs/n-02-tydzien-paschalny. pdf, [02.09.2021].

Schmemann, A. (1988). Za życie świata. Warszawa.

Wieczernia, jutrznia, prokimenony, alleluja, rozestania, kalendarz liturgiczny. (2006). Warszawa.

Rozmiar artykułu: 0,7 arkusza wydawniczego 